\title{
Wydawnictwo i czasopismo „Droga” jako ośrodek kształtowania ideologii społecznej i wychowawczej sanacji w latach 1922-1937
}

W dzieło kształtowania nowej powojennej rzeczywistości aktywnie włączyła się prasa polska. Stała się ona ważnym środkiem przekazywania informacji i kształtowania opinii publicznej w Polsce. Na jej oblicze ideowe wpływała mozaika polityczna II Rzeczypospolitej. Rozwój myśli ideologicznej, politycznej i pedagogicznej znajdował wówczas swoje odbicie nie tylko w oficjalnych dokumentach rządowych, ministerialnych i partyjnych, ale również w wydawnictwach i publicystyce ukazującej się na łamach opiniotwórczych czasopism.

Genezy przyszłego obozu ideowo-politycznego Józefa Piłsudskiego, nazywanego po przewrocie majowym „sanacją”, należy szukać w Organizacji Bojowej Polskiej Partii Socjalistycznej, Związku Walki Czynnej, organizacjach strzeleckich i I Brygadzie Legionów Polskich. Z czasem ta formacja typu pokombatanckiego, oparta o zasadę wodzostwa tworzyła prawdziwą mozaikę różnych orientacji politycznych, od socjalistów i syndykalistów, poprzez republikanów, ludowców, ludzi wywodzących się z legionowych środowisk kombatanckich, aż po konserwatystów. W skład obozu piłsudczykowskiego wchodziły, bezpośrednio po odzyskaniu niepodległości, grupy różne zarówno pod względem tradycji, jak i programu politycznego, związane z osobą J. Piłsudskiego, który był dla całego ruchu elementem integracji, a jego osoba stanowiła swoistą personifikację ideologii obozu.

U progu niepodległości grupy piłsudczyków konsolidowały się wokół wydawnictwa i redakcji „Drogi” i tygodnika „Głos Prawdy”.

„Drodze” jako głównemu organowi ideowemu i politycznemu piłsudczyków poświęcono we współczesnej historiografii niewspółmiernie mało uwagi, w stosunku

* Prof. zw. dr hab., Uniwersytet Gdański, Wydział Nauk Społecznych, Instytut Pedagogiki, Zakład Historii Nauki, Oświaty i Wychowania, 80-952 Gdańsk, ul. Bażyńskiego 4. 
do roli jaką to pismo i wydawnictwo odegrało w kształtowaniu ideologii i myśli politycznej obozu sanacyjnego.

"Droga", będąc głównym eksponentem programu ideowego i politycznego ruchu piłsudczykowskiego, ukazywała się przez 16 lat, w okresie od 1 lutego 1922 r. do sierpnia roku 1937. Obok Adama Skwarczyńskiego, inicjatorami powstania i twórcami tego organu teoretycznego piłsudczyków byli: Tadeusz Hołówko, Adam Koc, Jan Pohoski, Jan Rychlik-Swarzeński, Walery Sławek oraz Janusz Jędrzejewicz.

W latach 1922-1923 „Droga” ukazywała się jako dwutygodnik. W kwietniu 1923 r. nastąpiła zmiana częstotliwości wydawania pisma, które odtąd ukazywało się w cyklu miesięcznym, z wyeksponowanym podtytułem, jako „Miesięcznik poświęcony sprawie życia polskiego".

Biura redakcji i administracji wydawnictwa mieściły się w Warszawie, początkowo przy ulicy Szpitalnej 12, natomiast od roku 1925 przy ul. Chmielnej 33, gdzie swoją siedzibę posiadał także Powszechny Uniwersytet Korespondencyjny, będący sanacyjną instytucją oświatową, założoną przez A. Skwarczyńskiego i J. Jędrzejewicza.

Całość cyklu wydawniczego „Drogi” obejmuje 165 zeszytów, których objętość wahała się w granicach od 80 do 120 stron. W ciągu roku najczęściej ukazywało się 11 numerów, gdyż w okresie wakacyjnym często drukowano numer podwójny. Format pisma nie zmieniał się - wynosił $25 \mathrm{~cm}$ x $18 \mathrm{~cm}$. Szata graficzna mimo współpracy z różnymi drukarniami zmieniała się niewiele. Najdłużej łłoczono „Drogę" w warszawskiej Drukarni Artystycznej (1933-1937) przy Nowym Świecie 45, z którą współpracowała przez kilka lat również redakcja „Zrębu”. Wówczas także nieco zmieniono mało atrakcyjną i jednostajną szatę graficzną pisma, wprowadzając dwuszpaltowy układ kolumny w dziale recenzji oraz zróżnicowano krój czcionki. Począwszy od 1929 r., „Droga” ukazywała się ze stałą okładką, którą zaprojektował artysta-grafik Jan Kurzątkowski. Nakład miesięcznika nie jest znany, niemniej wziąwszy pod uwagę ideologiczny charakter pisma oraz nieustanne kłopoty finansowe redakcji i trudności z pozyskaniem nowych prenumeratorów, co pośrednio znajdowało odbicie na łamach „Drogi”, nie był wysoki i oscylował prawdopodobnie, jak podobne czasopisma, w granicach od 800 do 1200 egzemplarzy.

Marian Tyrowicz w przeprowadzonej analizie organizacji czasopiśmiennictwa naukowego w Polsce zaliczył „Drogę”, obok „Tygodnika llustrowanego”, „Myśli Narodowej”, „Przeglądu Współczesnego” i „Pamiętnika Warszawskiego”, do najlepszych wydawnictw ogólnokulturalnych, „które ogarniają całokształt współczesnej rzeczywistości"1.

Redaktorzy pisma zmieniali się kilkakrotnie. Pierwsze zeszyty w 1922 r. redagował Jan Goliński, następnie do kwietnia 1923 r. pismem kierował Stanisław Guliński. Od maja 1923 r. redakcję „Drogi” objął jej założyciel i główny ideolog obozu piłsudczykowskiego, A. Skwarczyński, który wpłynął w sposób decydujący na ukształtowanie się oblicza ideowego i profilu miesięcznika. Na początku $1927 \mathrm{r}$.

${ }^{1}$ M. Tyrowicz, Z zagadnień organizacji czasopiśmiennictwa naukowego w Polsce, „Droga” 1932, nr 4, s. 359. 
A. Skwarczyński, obejmując funkcję kierownika Referatu Społeczno-Prasowego w Kancelarii Cywilnej Prezydenta Rzeczypospolitej Polskiej, przekazał kierownictwo redakcji pisarzowi i filozofowi, dr. Stanisławowi Vincenzowi, autorowi m.in. utworów: Na wysokiej Połoninie, Wiatr nad Pokuciem i Zwady. A. Hertz w swoich pamiętnikach stwierdzał, że Vincenz finansował wydawanie pisma w pierwszych latach jego istnienia². Od października 1928 r. redakcję pisma objął Wilam Horzyca, redagując je wspólnie z Czesławem Bobrowskim, który do kwietnia 1929 r. pełnił funkcję zastępcy redaktora naczelnego. Ostatnia zmiana w składzie personalnym redakcji nastąpiła w maju 1935 r., kiedy to redaktorem odpowiedzialnym pisma został równoczesny redaktor "Wiedzy i Życia” Stanisław Podwysocki. Obaj z W. Horzycą kierowali miesięcznikiem do sierpnia 1937 r. Pod kierownictwem Horzycy nastąpiła wyraźna zmiana profilu pisma, które od 1931 r. stosunkowo najwięcej uwagi poświęcało sprawom kultury i sztuki oraz aktywnie włączyło się w kształtowanie programu wychowawczego sanacji.

W latach 1923-1927 zamieszczano w piśmie listy stałych współpracowników, których liczba przekraczała 50 osób. Byli wśród nich czołowi ideolodzy i politycy obozu piłsudczykowskiego oraz twórcy kultury. Do najbardziej znanych należeli m.in.: Antoni Anusz, Piotr Borkowski, Leopold Caro, Marceli Handelsman, Tadeusz Hołówko, Paweł Hulka-Laskowski, Juliusz Kaden-Bandrowski, Janusz Jędrzejewicz, Bogusław Miedziński, Mieczysław Niedziałkowski, Hanna Pohoska, Julian Poniatowski, Wacław Sieroszewski, Andrzej Strug, Stefan Starzyński, Kazimierz Świtalski, Stanisław Thugutt oraz Leon Wasilewski.

Ponadto autorami bardzo licznych artykułów i rozpraw zamieszczanych systematycznie na łamach „Drogi” byli m.in.: Piotr Dunin-Borkowski; będący w okresie rządów Kazimierza Bartla kolejno wojewodą poznańskim i Iwowskim, Julian Husarski, były sekretarz generał Komitetu Ekonomicznego Rady Ministrów i prezes Polskiego Towarzystwa Ekonomicznego, wreszcie Władysław Leopold Jaworski, profesor prawa cywilnego na Uniwersytecie Jagiellońskim, inicjator monumentalnego wydawnictwa pt. Prawa państwa polskiego, mającego na celu systematyzację polskiego ustawodawstwa, a także autor Projektu konstytucji (Kraków 1928), wydanej w dwóch tomach. Zaledwie dziewięć miesięcy po śmierci tego wybitnego uczonego ukazała się obszerna praca zbiorowa pod redakcją Stanisława Estreichera pt. W. L. Jaworski - Życie i działalność (Kraków 1931), poświęcona analizie jego poglądów i dzieł z zakresu filozofii i prawa.

Autorami najpoważniejszych rozpraw historycznych publikowanych w „Drodze" byli: Władysław Pobóg-Malinowski, prof. Tadeusz Zieliński i prof. Stanisław Zakrzewski, prezes Polskiego Towarzystwa Historycznego. Problemy z zakresu kultury i literatury rozpatrywali m.in. profesorowie: Zygmunt Łempicki i Stefan Kołaczkowski. Zagadnienia filozoficzne na łamach miesięcznika podejmowali: Kazimierz Jaworski, Bolesław Gawęcki, Adam Zieleńczyk i Stanisław Ignacy Witkiewicz.

Autorem oryginalnych rozpraw filozoficznych, m.in. zamieszczanych w „Drodze", był ksiądz Augustyn Jakubisiak, duszpasterz kolonii polskiej w Paryżu. Początkowo jego zainteresowania naukowe dotyczyły filozofii polskiej, przede

${ }^{2}$ A. Hertz, Wyznania starego człowieka, Oficyna Poetów i Malarzy, Londyn 1979, s. 288-290. 
wszystkim myśli Augusta Cieszkowskiego i Józefa Marii Hoene-Wrońskiego. Następnie zajął się analizą poglądów Immanuella Kanta. Najpoważniejszym jednak jego dziełem była praca teoriopoznawcza opublikowana w języku francuskim pt. Rozprawa o granicach przestrzeni i czasu (Paryż 1927), nagrodzona przez francuską Akademię Nauk Moralnych i Politycznych.

„Droga” nie posiadała nigdy oficjalnego Komitetu Redakcyjnego, mimo to od 1931 r. funkcje redaktorów wyodrębnionych działów pełnili: Jan Feldman i Roman Koroniecki. Materiał przeznaczony do publikacji grupowano bowiem w dwóch zasadniczych działach. W części głównej zamieszczano rozprawy i artykuły o charakterze naukowym lub publicystycznym, dotyczące najczęściej problemów ideologiczno-politycznych, moralno-religijnych, polityki gospodarczej oraz kwestii mniejszości narodowych.

W latach trzydziestych dominowały natomiast zagadnienia z dziedziny kultury, literatury, nauki, spraw społeczno-gospodarczych i wychowania. W dziale tym zamieszczano również często fragmenty literatury pięknej, utwory poetyckie oraz krótkie nowele i opowiadania. Dział drugi stanowił przegląd sprawozdawczy poświęcony polityce polskiej i zagranicznej, życiu kulturalnemu oraz recenzjom teatralnym i książkowym. Na łamach „Drogi”, szczególnie od 1928 r., publikowali swe utwory literackie wszyscy czołowi polscy prozaicy i poeci. Stosunkowo najczęściej prezentowali czytelnikom pisma swoją twórczość: Jerzy Braun, Konstanty Ildefons Gałczyński, Józef Czechowicz, Jarosław Iwaszkiewicz, Mieczysław Jastrun, Maria Pawlikowska-Jasnorzewska, Jan Lechoń, Julian Tuwim, Adam Ważyk i Kazimierz Wierzyński. Sporadycznie swoje utwory zamieszczali ponadto: Jerzy Andrzejewski, Stanisław Ryszard Dobrowolski, Jalu Kurek, Czesław Miłosz, Hanna Mortkowiczówna, Julian Przyboś i Józef Wittlin.

Redakcja adresowała pismo w szczególności do inteligencji. A. Hertz w artykule opublikowanym z okazji dziesięciolecia miesięcznika pisał, że jest on „organem tych kół, które zwykło się nazywać elitą intelektualną"”. Stwierdzenie Hertza, uzasadnione profilem i wysokim poziomem merytorycznym pisma, znacznie zawężało zasięg jego potencjalnego oddziaływania. Jako główne zadanie „Drogi” uważano wypracowanie programu ideowego i politycznego obozu rządowego oraz „nowego światopoglądu - różnego od liberalizmu i katolicyzmu”. W swej programowej publikacji A. Hertz wyraźnie określa profil i charakter periodyku, stwierdzając, że „Droga” jest pismem światopoglądowym i publicystycznym, jest pismem poświęconym sprawie życia polskiego, walczącą o treść ideową tego życia" ${ }^{\text {. }}$.

W pierwszych latach swego istnienia „Droga” stanowiła również oficjalny organ prasowy Polskiej Organizacji Wolności (POW). Związek został utworzony w dniach 25-26 czerwca 1922 r. w Warszawie na ogólnopolskim zjeździe delegatów byłych członków Polskiej Organizacji Wojskowej. Przewodniczącym Zarządu Tymczasowego organizacji byłych „peowiaków” został znany pisarz - Andrzej Strug, funkcję sekretarza pełnił natomiast Lucjan Zarzycki. Inicjatorami powstania

\footnotetext{
${ }^{3}$ A. Hertz, Przed dalszą drogą, „Droga” 1932, nr 2, s. 111.

${ }^{4}$ Tamże, s. 113.

${ }^{5}$ Tamże, s. 118.
} 
związku oraz członkami jego władz byli ponadto m.in.: Juliusz Poniatowski, Tadeusz Niedzielski i Stanisław Twardo. Sekretariat POW mieścił się w lokalu redakcji „Drogi” przy ulicy Szpitalnej 12 m. 296. W myśl uchwały zjazdowej i instrukcji prasowej POW, „Droga” pełniła funkcję organu prasowego tegoż związku, ogłaszała jego uchwały i zarządzenia, zaś artykuły publicystyczne zamieszczane na jego łamach miały być „dla kierowników i członków organizacji materiałem ideowym, instrukcyjnym i informacyjnym"?.

Zespół ideowy oraz współpracownicy skupieni wokół redakcji „Drogi” byli inicjatorami powstania innej organizacji piłsudczykowskiej - Konfederacji Ludzi Pracy. W skład jej Komitetu Organizacyjnego zawiązanego w kwietniu 1924 r., spośród najbliższych współpracowników miesięcznika wchodzili: Stefan Boguszewski, Wilam Horzyca, Juliusz Husarski, Janusz Jędrzejewicz oraz Adam Skwarczyński . Również dla tej organizacji, niepełniącej podobnie jak POW roli partii politycznej, lecz będącej raczej związkiem o charakterze społeczno-wychowawczym, pismo spełniało zadania organu prasowego. Do numeru kwietniowego z 1924 r. redakcja dołączyła program i deklarację ideową KLP, wydaną nakładem miesięcznika.

Metodą pracy redakcji i współpracowników „Drogi” było tworzenie zespołów ideowo-dyskusyjnych w celu wypracowania ideologii oraz stanowiska ruchu piłsudczykowskiego wobec aktualnych problemów społeczno-politycznych, kulturalnych, stosunku do religii i mniejszości narodowych. Jednym z największych osiągnięć w tym zakresie było opracowanie programu politycznego ruchu piłsudczykowskiego, z którym wystąpił publicznie z ramienia „Drogi” - Stefan Starzyński, ogłaszając drukiem w kwietniu 1926 r. Program rządu pracy w Polsce.

Redakcja „Drogi” prowadziła bardzo ożywioną działalność wydawniczą. Nakładem tegoż miesięcznika ukazywały się trzy serie: „Biblioteka Drogi” - o charakterze ideowo-politycznym, „Biblioteka Poetycka” oraz redagowana przez W. Horzycę - „Biblioteka Dramatyczna”. Ponadto od 1923 r. do wybranych numerów pisma redakcja dołączała, uprzednio reklamowane w miesięczniku i zamówione przez prenumeratorów, oddzielne dodatki książkowe, dotyczące zagadnień społeczno-politycznych, które nie były ujęte w odrębny cykl wydawniczy. Do 1933 r., kiedy to zarzucono tę formę wydawniczą, ukazało się 20 pozycji, z których kilka w latach 1923-1924 zostało wydanych na zlecenie „Drogi” przez Towarzystwo Wydawnicze Ignis.

Jako najciekawsze spośród dodatków książkowych należy uznać prace: Piotra Dunina Borkowskiego Tendencje ustrojowe w Polsce (Warszawa 1928), Bolesława Wścieklicy Państwo syndykalne (Warszawa 1929), Mariana Uzdowskiego Eurazjanizm (Warszawa 1928); ta ostatnia poświęcona analizie programu politycznego jednego z kierunków ideologicznych antykomunistycznej emigracji rosyjskiej; wreszcie Romana Kołonieckiego Społeczne zadania literatury (Warszawa 1933),

6 Tamże, 1922, nr 11, s. 20-26.

7 A. Skwarczyński, Zamiast haseł - praca, tamże, nr 14-15, s. 37.

${ }^{8}$ A. Bełcikowska, Stronnictwa i związki polityczne w Polsce, Dom Książki Polskiej, Warszawa 1925 , s. 817. 
omawiająca nowy kurs polityki kulturalnej rządu, zapoczątkowany powołaniem do życia Polskiej Akademii Literatury.

$\mathrm{Na}$ osobną uwagę zasługuje również publikacja wydana pod redakcją A. Skwarczyńskiego pt. Pod znakiem odpowiedzialności i pracy (Warszawa 1933), będąca plonem dziesięciu spotkań dyskusyjnych, mająca na celu wypracowanie programu obozu rządowego, obejmującego wszystkie dziedziny życia państwowego. Oddzielną grupę publikacji stanowiły ponadto dwa obszerne, zbiorowe wydawnictwa poświęcone polityce ekonomicznej państwa: Na froncie gospodarczym - 1918-1929 (Warszawa 1928) i Pięć lat na froncie gospodarczym - 1926-1931 (t. 1 i 2, Warszawa 1931).

W ramach podstawowego wydawnictwa „Biblioteki Drogi” ukazało się 8 publikacji, z których na wyróżnienie zasługują dwie prace profesora Wacława Makowskiego: Nowa Polska w Nowej Europie (t. 3, Warszawa 1930) i Państwo społeczne (t. 8, Warszawa 1936), obie postulujące przeprowadzenie zmian ustrojowych w Polsce i uspołecznienie państwa w oparciu o zasady solidaryzmu społecznego. Program ustrojowy polskich syndykalistów był z kolei przedmiotem rozprawy K. Zakrzewskiego pt. Kryzys demokracji (Warszawa 1930), wydanej jako drugi tom „Biblioteki Drogi”. A. Hertz w książce pt. Ludzie i idee (t. 6, Warszawa 1931) skupił się natomiast przede wszystkim na przedstawieniu i rozwinięciu teorii elity, autorstwa Vilfreda Pareto.

W cyklu „Biblioteki Dramatycznej” wydano 12 tekstów będących wybitnymi osiągnięciami współczesnej dramaturgii światowej w przekładzie m.in. Wilama Horzycy, Romana Kołonieckiego, Zbigniewa Przesmyckiego, Heleny Mysłakowskiej i Stanisława Helsztyńskiego. W ramach „Biblioteki Poetyckiej” ukazało się 6 zbiorów utworów Józefa Czechowicza, Henryki Łazowertównej, Paula Valeiy’ego i Romana Kołonieckiego.

Redaktorzy i publicyści „Drogi” duże znaczenie przywiązywali do określenia rodowodu ideowego obozu sanacyjnego, którego poszukiwali przede wszystkim w tradycji polskiego romantyzmu i mesjanizmu oraz walk o wyzwolenie narodowe. Nie mniej ważnym problemem, często podnoszonym na łamach pisma, były zagadnienia filozoficzne omawiane w celu wypracowania podstaw filozoficznych i historiozoficznych ideologii piłsudczykowskiej. Najczęściej odwoływano się w tej kwestii również do poglądów przedstawicieli polskiego romantyzmu, głównie zaś Maurycego Mochnackiego, Kazimierza Brodzińskiego, Karola Libelta, Andrzeja Towiańskiego oraz Józefa Marii Hoene-Wrońskiego, któremu poświęcono kilka oddzielnych publikacji ${ }^{9}$. Równie popularnym i często cytowanym myślicielem, którego sylwetkę oraz twórczość filozoficzną kilkakrotnie przedstawiano na łamach miesięcznika, był Rudolf Maria Holzapfel ${ }^{10}$. W 1927 r. została wydana w War-

9 M.in.: A. Zieleńczyk, Hoene-Wroński, „Droga” 1928, nr 6, s. 529-545 i nr 7, s. 709-731; tenże, Zagadnienia filozofii narodowej, tamże, 1929, nr 1, s. 35-45; B. Gawecki, Współczesne zadania filozofii, tamże, 1936, nr 10, s. 801-816; J. Jankowski, Ekonomia społeczna Hoene-Wrońskiego, tamże, 1931, nr 3, s. 220-230 i nr 4, s. 333-345.

${ }_{10}$ R. Roland, Rudolf Maria Holzapfel, tamże, 1925, nr 11, s. 18-26; A. B. Dobrowolski, Rudolf Maria Holzapfel i podstawy naukowe wychowania uczuć, tamże, 1927, nr 1-33, s. 22-39. 
szawie książka R. M. Holzapfela pt. Das Paindeal (Wszechideał) w przekładzie S. Vincenza, który był gorliwym wyznawcą i propagatorem jego filozofii.

Często poruszanymi na łamach „Drogi” tematami były zagadnienia dotyczące ustroju politycznego Polski, zmiany Konstytucji marcowej, koncepcji uspołecznienia państwa, inteligencji i jej roli w społeczeństwie oraz problemów ekonomicznych w duchu interwencjonizmu państwowego i polityki zagranicznej. Kolejna grupa zagadnień tematycznych dotyczyła problemów moralnych, powinności i obowiązków obywatelskich oraz stosunku jednostki do państwa, a także kultury ze szczególnym eksponowaniem roli literatury.

Kwestia mniejszości narodowych i polityki państwa w tym zakresie komentowana była w "Drodze” na bieżąco. Wypowiadali się na ten temat wybitni znawcy przedmiotu, m.in.: Tadeusz Hołówko, Piotr Dunin-Borkowski, Adolf M. Bocheński, Stanisław Poźniak, Stanisław Łoś i Leon Wasilewski. Wszyscy politycy zajmujący się tą problematyką jednoznacznie występowali przeciwko tendencjom asymilacji mniejszości narodowych. Poprzez nadanie Ukraińcom i Białorusinom szerokiego samorządu lokalnego w postaci autonomii terytorialnej oraz zapewnienia swobód kulturalno-narodowych, postulowano pozyskanie ich dla państwowości polskiej11. Wypowiadano się również przeciwko wszelkim formom ostracyzmu społecznego wobec ludności żydowskiej ${ }^{12}$. Założenia piłsudczykowskiej polityki narodowościowej były niewątpliwie postępowe i jakościowo odmienne w porównaniu z poglądami reprezentowanymi $w$ tej kwestii przez polskich nacjonalistów, skupionych w obozie narodowym, którzy często zaprzeczali odrębności narodowej Ukraińców, traktując ich jako element folklorystyczny, stanowiący materiał do akcji polonizacyjnej ${ }^{13}$.

Żywo interesując się polityką mniejszościową oraz doceniając wagę problemu, redakcja „Drogi” ogłosiła w numerze piątym z 1924 r. ankietę pt. Sprawa kresów wschodnich oraz zamieściła tekst Memoriału w sprawie kresów, opracowanego przez Wileńskie Biuro Prac Politycznych i wręczonego w styczniu 1925 r. rządowi polskiemu ${ }^{14}$. Biuro, stwierdzając niepowodzenia i szkodliwość realizowanej przez rząd polityki narodowościowej, wysuwało kompleksowy program rozwiązania problemu, eksponując szczególnie postulaty decentralizacji administracji, autonomii terytorialnej i Kościoła prawosławnego, reformy rolnej oraz polityki gospodarczej.

Jednym z zasadniczych postulatów Memoriału było zrewidowanie polityki oświatowej wobec mniejszości. W tym kontekście została poddana krytyce ustawa Stanisława Grabskiego z 31 lipca 1924 r. O szkolnictwie utrakwistycznym. Postulowano także swobodny rozwój szkolnictwa ukraińskiego i białoruskiego, utworzenie seminariów nauczycielskich kształcących kadry dla potrzeb tego

11 M.in.: J. Grabiec, W sprawie polityki narodowościowej, tamże, 1924, nr 8, s. 13-23; T. Hołówko, Minimalny program polityki polskiej we wschodniej Galicji i na tzw. kresach, tamże, 1931, nr 10, s. 4-14; S. Poźniak, Zagadnienie białoruskie, tamże, nr 10, s. 543-561; B. Wścieklica, Polityka gospodarcza wobec ziem wschodnich, tamże, 1935, nr 1, s. 1-18.

12 J. Polak, Sprawa żydowska, tamże, 1929, nr 8, s. 47-59.

13 A. M. Bocheński, Polityczne oblicze asymilacji narodowej, tamże, 1935, nr 6, s. 489-508.

14 Wileńskie Biuro Prac Politycznych. Memoriał w sprawie kresów, tamże, 1925, nr 1, s. 17-53. 
szkolnictwa oraz powołanie Uniwersytetu Ukraińskiego we Lwowie i katedry białorusoznawstwa na Uniwersytecie Wileńskim. Ponadto autorzy dokumentu uzasadniali potrzebę powołania do życia Szkolnych Rad Narodowych oraz utworzenie Wydziałów Narodowościowych przy Ministerstwie WRiOP i Kuratoriów Okręgów Szkolnych, których obsada personalna miała być konsultowana w porozumieniu z Radami Szkolnymi zainteresowanych narodowości.

T. Hołówko ${ }^{15}$ w jednej z kilku publikacji, poświęconych kwestii narodowościowej, znacznie rozszerzał zakres postulatów zawartych w Memoriale. Uważał m.in., że we wszystkich polskich seminariach nauczycielskich w województwach wschodnich powinna być prowadzona nauka języka, literatury i historii ukraińskiej, względnie białoruskiej, aby przyszli nauczyciele mogli autentycznie działać w celu zbliżenia kultury narodów. Podobny postulat odnosił także do wszystkich polskich szkół średnich ogólnokształcących znajdujących się na tzw. kresach.

W kwestii szkolnictwa wyższego, aprobując ideę utworzenia Uniwersytetu Ukraińskiego we Lwowie oraz katedr języka, etnografii i literatury białoruskiej na Uniwersytecie Wileńskim, T. Hołówka proponował ponadto powołanie Wyższego Instytutu Pedagogicznego oraz Wyższej Szkoły Agronomiczno-Handlowej na Wołyniu. Wyrażając opinię redakcji i wielu czołowych polityków sanacyjnych, główny cel polityki narodowościowej formułował następująco: „ludności ukraińskiej i białoruskiej zamieszkałej w Polsce dać możność żyć pełnią życia narodowego, kulturalnego, politycznego i religijnego, otoczyć jej potrzeby ekonomiczne i społeczne rozumną i stałą opieką ze strony państwa"16.

Równie liberalne zasady polityki oświatowej wobec mniejszości narodowych formułował inny publicysta „Drogi” Stanisław Łoś w pracy pt. O konstruktywną politykę na Rusi Czerwonej (Warszawa 1931). Nakładem miesięcznika ukazała się ponadto na początku 1926 r. książka Zygmunta Dreszera pt. Mniejszości narodowe w Polsce (Warszawa 1926).

W okresie rządów sanacji nie nastąpiła jednak radykalna zmiana kursu polskiej polityki narodowościowej. Spośród piłsudczyków czołowi twórcy i propagatorzy alternatywnej wobec programu asymilacji narodowej wizji polityki mniejszościowej nie kryli w tej kwestii swego rozczarowania. Wyrazem nastrojów tej grupy polityków był m.in. opublikowany w „Drodze” artykuł T. Hołówki pod znamiennym tytułem Dlaczego jeszcze tyle nieprawości (1926, nr 9, s. 1-5).

Osobną grupę publikacji zamieszczonych na łamach „Drogi” stanowiły artykuły mające na celu określenie stosunku ruchu piłsudczykowskiego do kwestii wyznaniowej, w tym przede wszystkim do religii katolickiej. Większość autorów piszących na ten temat podkreślała potrzebę tolerancji religijnej oraz równouprawnienia wszystkich wyznań i Kościołów. Krytycznie ustosunkowywano się do ustaleń zawartego 11 lutego 1925 r. konkordatu z Watykanem, który - jak stwierdzał T. Hołówko - „rozumie go w ten sposób, że państwo winno w dziedzinie religijnej być ślepym narzędziem interesów polityki Watykanu"17. Klerowi za-

15 T. Hołówko, Metody i drogi sanacji stosunków we wschodniej Galicji i województwach wschodnich, tamże, 1926, nr 5, s. 46-55.

16 Tamże, s. 55.

17 T. Hołówko, Dlaczego jeszcze tyle nieprawości, tamże, nr 9, s. 3. 
rzucano zaś niskie wykształcenie, aspołeczność oraz rozpolitykowanie i działanie na rzecz reakcyjnych partii politycznych ${ }^{18}$.

Główny spośród współpracowników pisma antagonista Kościoła katolickiego, P. Hulka-Laskowski, wytyczną programu piłsudczyków w tej kwestii formułował w sposób następujący: „okiełzać klerykalizm zachłanny. To jest nasze ceterum censco"19. W toku rozwiniętej na łamach „Drogi” w 1926 i 1927 r. ciekawej dyskusji poświęconej zagadnieniom odrodzenia moralnego i religijnego społeczeństwa, jedynie prof. L. Caro zdecydowanie przeciwstawił się postulatom walki z katolicyzmem, uważając za stosowne ścisłe współdziałanie państwa z Kościołem w celu podniesienia poziomu etycznego narodu ${ }^{20}$.

„Droga”, jako centralny organ teoretyczny ruchu piłsudczykowskiego, poświęcony wypracowaniu ideologii i programu obozu, stanowiła również w założeniach swych twórców ośrodek długofalowej pracy wychowawczej, kształtujący także doktrynę pedagogiczną sanacji. Zamiar stworzenia nowego programu wychowawczego, alternatywnego przede wszystkim wobec doktryny wychowania narodowego, przyświecał organizatorom wydawnictwa, począwszy od 1922 r. W artykule redakcyjnym otwierającym pierwszy numer pisma poddano krytyce dotychczasowy system kształcenia i wychowania oraz sformułowano postulat wypracowania nowego ideału i programu wychowawczego odpowiadającego potrzebom polskiej państwowości. Jego założenia były jednak jeszcze bardzo mgliste, sprowadzone praktycznie do haseł wychowania „człowieka woli i czynu, człowieka pracy i myśli zbiorowej"21.

Podobnie dwie kolejne publikacje z 1922 r., autorstwa Janusza Jędrzejewicza $^{22}$ i Kazimierza Kosińskiego ${ }^{23}$ - przyszłych twórców „Zrębu”, również nie wykraczały poza ogólniki oraz nieskonkretyzowane postulaty wychowania człowieka nowego typu i obywatela odznaczającego się heroizmem woli oraz szacunkiem dla pracy.

Publicyści „Drogi” interesowali się także początkowo specyfiką wychowania wojskowego, w odniesieniu do którego mieli wyraźnie sformułowane poglądy w kwestii określenia celów, zadań i metod jego realizacji. Wynikało to zapewne z tradycji legionowych oraz doświadczeń nabytych w okresie formowania regularnej armii polskiej.

W całokształcie pracy wychowawczej w wojsku eksponowano przede wszystkim rolę wychowania moralnego zarówno w zakresie kształtowania indywidualności żołnierza, jak również poczucia zbiorowego działania i życia ${ }^{24}$. Należy sądzić, że piłsudczycy, nie mając żadnych tradycji ani doświadczeń w zakresie organizacji systemu kształcenia i wychowania całego społeczeństwa, próbowali poszukiwać

18 P. Hulka-Laskowski, Słowa i czyny, tamże, nr 11, s. 27.

19 Tamże, s. 29.

20 L. Caro, Katolicyzm a sprawa polska, tamże, 1927, nr 4-5, s. 45-58.

21 O władzę życia [artykuł redakcyjny], tamże, 1922, nr 1, s. 1-6.

22 J. Jędrzejewicz, O nowego człowieka, tamże, nr 2, s. 1-3.

23 K. Kosiński, Szkoła a człowiek nowy w Polsce, tamże, nr 3, s. 4-10.

24 J. R. Swarczyński, Metody i zadania wychowania wojskowego, tamże, nr 2, s. 4-12 i nr 4 s. $5-12$. 
w tej mierze wzorów w organizacji wychowania wojskowego, które były im niewątpliwie bliższe.

Można więc stwierdzić, że już w 1922 r. piłsudczycy zainicjowali na łamach „Drogi” prace dotyczące wypracowania własnej ideologii wychowawczej. Nie był to jeszcze nawet zarys programu, lecz raczej wyraźne poszukiwanie jego konstytutywnych haseł i wartości. Odwołując się do tradycji niepodległościowej oraz wymagań rzeczywistości niepodległej państwowości, sformułowany został postulat wychowania obywatelskiego, rozwinięty teoretycznie dopiero po $1928 \mathrm{r}$. Nowym elementem, który na trwałe został później włączony do zestawu założeń koncepcji wychowawczej sanacji, było akcentowanie roli czynnika emocjonalnego w wychowaniu.

Po dojściu obozu piłsudczykowskiego do władzy, w numerze czerwcowym „Drogi” z 1926 r. ukazał się artykuł G. Linca pt. Potrzeba rewolucji w wychowaniu (1926, nr 6-7, s. 13-21), który w sposób jednoznaczny oddawał istotę zamierzeń sanacji w dziedzinie oświaty. Publicysta ten skupił się przede wszystkim na krytyce ideałów wychowawczych endecji oraz polityki oświatowej wobec mniejszości narodowych. Wykazywał również bezideowość oraz niedomagania wychowawcze szkolnictwa wszystkich typów i szczebli. Nakreślony jednak przez Linca program pozytywny był jeszcze bardzo ubogi. Autor nie precyzował bowiem na czym rewolucja w wychowaniu miałaby polegać. Nie formułował także nowego ideału wychowawczego, ograniczając się jedynie do stwierdzenia, że należy wychowywać młode pokolenie w oparciu o żywy autorytet, wzór osobowy i idee J. Piłsudskiego.

Sformułowaniem przesłanek patriotyzmu nowego typu zajął się Joachim Wołoszynowski w artykule pt. Państwowe nastawienie umysłów (1927, nr 8-10, s. 1-6). Akcentując głównie intelektualną stronę patriotyzmu, wskazywał na potrzebę zrozumienia przez obywateli współzależności interesów jednostek z celami społeczeństwa zorganizowanego w instytucji państwa.

Publikacją, która w sposób najbardziej wszechstronny omawiała podstawowe założenia doktryny wychowawczej sanacji, był artykuł Wiktora Niechaya pt. Problem wychowania państwowego (1931, nr 4, s. 346-357). Autor podjął się nie tylko sprecyzowania ideału i zadań wychowania państwowego, ale również określił metody i środki jego realizacji w praktyce pedagogicznej. Jako interesującą w tym zakresie należy uznać przystosowaną do potrzeb realizacji celów wychowania państwowego koncepcję organizacji życia oraz działalności gmin klasowych i szkolnych. Na uwagę zasługują również ciekawie opracowane przez Niechaya cele pracy wychowawczej szkoły, z których na czoło wysuwał m.in. kształtowanie postaw altruizmu społecznego oraz umiejętne wykorzystanie dla ich realizacji organizacji i instytucji uczniowskich.

Obok niewątpliwie ciekawych spostrzeżeń, stanowiących istotny wkład w kształtowanie rządowej doktryny wychowawczej, autor rozprawy nie ustrzegł się jednak błędnej w swej istocie tendencji totalitaryzmu w wychowaniu. Za taką bowiem należy uznać sformułowany przez niego postulat konieczności tworzenia szkół z systemem internatowym ${ }^{25}$, w celu ułatwienia indoktrynacji oraz roztoczenia możliwie pełnej kontroli nad życiem i działalnością uczniów.

${ }^{25}$ W. Niechay, Problem wychowania państwowego, tamże, 1931, nr 4, s. 354. 
Drugą grupę zamieszczonych na łamach „Drogi” publikacji dotyczących zagadnień oświatowych stanowiły rozprawy poświęcone ustrojowi i organizacji szkolnictwa. Do najważniejszych spośród nich należy zaliczyć artykuły Bolesława Wścieklicy ${ }^{26}$, Ignacego Czumy ${ }^{27}$ oraz Bolesława Kielskiego ${ }^{28}$.

B. Wścieklica, specjalizujący się w problematyce ekonomicznej, w dwóch artykułach z 1929 r. poddał krytyce stan szkolnictwa zawodowego w Polsce oraz zaproponował kierunki reformy szkolnictwa tego typu. Część postulatów autora, dotycząca m.in. konieczności harmonizowania rozwoju szkolnictwa zawodowego z potrzebami gospodarki, współpracy administracji szkolnej z przedstawicielami kapitału i organizatorami produkcji, zmiany struktury, drożności oraz rozmieszczenia terytorialnego szkolnictwa zawodowego, znalazła swoje odzwierciedlenie w ustawie szkolnej z 1932 r., w której właśnie dział szkolnictwa zawodowego został niewątpliwie najlepiej opracowany.

Również zagadnieniu zmiany ustroju szkolnego poświęcona była rozprawa prof. I. Czumy uzasadniająca z kolei potrzebę reformy szkolnictwa akademickiego, której projekt został wypracowany przy jego znacznym udziale. Autor artykułu, wychodząc z założenia, że „reforma ustroju szkół akademickich winna zapoczątkować reformę wychowania młodzieży studiującej"29, próbował określić funkcje wychowawcze szkół wyższych, które w obowiązującej ustawie z 13 lipca 1920 r. były raczej pominięte.

Redakcja „Drogi” dopuszczała do głosu na łamach miesięcznika różne, często sprzeczne ze sobą ideowo koncepcje i nastawienia. Przykładem otwartości pisma w kwestii wypracowania programu wychowawczego sanacji było m.in. opublikowanie rozprawy Konrada Górskiego ${ }^{30}$ omawiającego rolę i zadania młodzieży we współczesnym społeczeństwie z punktu widzenia katolicyzmu i pedagogiki personalistycznej.

Niewątpliwą zasługą omawianego tu wydawnictwa było, jak starano się wykazać, zapoczątkowanie prac nad sformułowaniem nowego ideału wychowawczego oraz oryginalnej koncepcji wychowawczej obozu rządowego, nazywanej „wychowaniem państwowym”. Miała być ona alternatywą wobec endeckiej doktryny wychowania narodowego.

Liczne rozprawy i artykuły o charakterze programowym i ideologicznym stanowiły podstawę teoretyczną oraz uzasadniały potrzebę wypracowania przez obóz piłsudczykowski własnej doktryny pedagogicznej oraz organizacji ogólnospołecznego systemu wychowania. Jako ważny należy uznać wkład „Drogi” do sprawy określenia stosunku sanacji i prezentowanej przez nią doktryny do mniejszości narodowych oraz zagadnień światopoglądowych, w tym przede wszystkim, religii katolickiej.

${ }^{26}$ B. Wścieklica, Zasadnicze czynniki postępu gospodarczego i ich rola w Polsce, tamże, 1929, nr 3, s. 225-240; tenże, Życie gospodarcze i szkoła, tamże, nr 7-8, s. 628-637.

27 I. Czuma, O nowy ustrój szkół akademickich, tamże, 1933, nr 3, s. 209-228.

${ }_{28}$ B. Kielski, Nowa organizacja nauczania i wychowania w Polsce, tamże, 1932, nr 7-8, s. $726-737$.

29 I. Czuma, O nowy ustrój szkół akademickich, s. 228.

30 K. Górski, Rola młodzieży współczesnej, tamże, 1931, nr 1, s. 47-55. 
Artykuł G. Linca otworzył nowy etap systematycznej i zorganizowanej działalności koncepcyjnej nad wypracowywaniem doktryny wychowania państwowego. Publikacje W. Niechaya i J. Wołoszynowskiego istotnie wzbogaciły jej część teleologiczną, natomiast rozprawy B. Wścieklicy i J. Czumy uzasadniały oraz wytyczały kierunki przeprowadzonej po 1932 r. przez władze oświatowe reformy ustroju szkolnego. Niewątpliwie zatem grono czołowych ideologów, polityków i publicystów piłsudczykowskich skupionych wokół wydawnictwa „Drogi” wniosło znaczący wkład w kształtowanie ideologii wychowawczej sanacji oraz określenie niektórych założeń polityki oświatowej rządu.

Począwszy od 1937 r., w związku z likwidacją „Drogi”, podobną rolę również w zakresie wypracowywania nowych podstaw filozoficznych i ideologicznych rewidowanej wówczas doktryny wychowawczej sanacji starał się odgrywać, z mniejszym jednak powodzeniem, tygodnik „Zaczyn”, związany z Obozem Zjednoczenia Narodowego ${ }^{31}$.

${ }^{31}$ K. Jakubiak, Wychowanie państwowe jako ideologia wychowawcza sanacji, Bydgoszcz 1994, s. $120-128$. 